\title{
Problems Faced by Women Entrepreneurs in Thoothukudi District
}

\author{
D. Shakila ${ }^{\mathrm{a}}$, Dr. A.M. Tony Melwyn ${ }^{\mathrm{b}}$ \\ a M.Com., M.Phil., Research Scholar (Reg No: 20112101012001), Kamaraj College (Affiliated to ManonmaniamSundaranar \\ University, Tirunelveli), \\ Thoothukudi \\ ${ }^{b}$ M.Com., M.Phil., Ph.D., M.F.M., AssociateProfessor and Director of Self-Financing Courses, KamarajCollege(Affiliated to \\ ManonmaniamSundaranar University, Tirunelveli), \\ Thoothukudi
}

Article History: Received: 10 November 2020; Revised 12 January 2021 Accepted: 27 January 2021; Published online: 5 April 2021

\begin{abstract}
Women entrepreneurship is the process of setting up an enterprise, picking on any risks in the faith of profit. Women are these days winning in each and every field identical to men. Women entrepreneurs play a massive role in this male dominated society. Women are abutting lots of changes and problems prevailing in this society. Empowering women in entrepreneurship commands to break the inequalities and decreases scarcity. Basically entrepreneurs come across with many hardships that limit their prosperity and longevity. Besides this, women are working very excellently but they have many barriers in initiating and running their own business because of family problem, problems of finance, scarcity of Raw Materials, marketing constraints, numerous standards and customs etc. This paper helps to understand the countless problems faced by women entrepreneurs in the study area and suggests several measures to overcome those problems
\end{abstract}

Keywords: Women Entrepreneurs, Problems of Women Entrepreneurs, Entrepreneurship Development.

\section{Introduction}

Entrepreneurship come out from an individual's inspired essence into everlasting business proprietorship, employment formation, capital emergence and economic preservation. This expertise is an integral part of industrialization and serves as a remedy for mass unemployment and scarcity. Women entrepreneurship must be organized well with entrepreneurial traits and skills to meet the changing directions, threat worldwide market and also be proficient enough to suffer and tackle to gain recognition in the entrepreneurial field.

Women entrepreneurs produce special requirements by increasing their economic status in the society. Primarily women establish small scale enterprises later develop it into a large scale enterprise. Every woman entrepreneur venture to guard and earn profit thereby contributing to the nation building.

Women entrepreneurs try to make a new territory and overcome all the barriers which they face in this patriarchal society. Nowadays women entrepreneurs are much efficient in tackling the problems and use strategic solutions or technique to run the business prosperously. Women entrepreneurs run their enterprises equally as men counterparts. This shows they are deeply empowered in this society. Each and every successful woman entrepreneur has faced and failed all sorts of conflicts while attempt to sustain their business with their determination, which has influenced the society positively by contributing many offers and chances to many people.

\section{Objectives Of The Study}

The research paper has the following objectives:

1. To understand the problems faced by women entrepreneurs in the study area.

2. To find out the ways to overcome the problems faced by them.

\section{Scope Of The Study}

The present study discloses the problems faced by women entrepreneurs in Thoothukudi district. The data was scrutinized based on details gathered from the women entrepreneurs. The study also focuses on the various problems like Marketing, Finance, Human resource and Production problem faced by women entrepreneursin the study area and which hinders the success and development of women entrepreneurship. 


\section{Methodology}

Data was concluded and composed from 30 women entrepreneurs in Thoothukudi district. Primary data was gathered from questionnaires targeted from various women entrepreneurs. Secondary data was referred and taken from different published books, websites, journals, etc.

\section{Sample For The Study}

Stratified random sampling method was used. The sample size of the present study is 30 women entrepreneurs.

\section{Tools For Analys}

Appropriate statistical tools like Percentage Analysis and Chi-Square Test were applied to analyse the data and to draw viable conclusions.

\section{7.. Hypotheses}

a) Research Hypothesis $\left[\mathrm{H}_{1}\right]$ : There is a significant relationship between age of the respondents and the overall problems faced by women entrepreneurs.

b) Null Hypothesis $\left[\mathrm{H}_{0}\right]$ : There is no significant relationship between age of the respondents and the overall problems faced by women entrepreneurs.

\section{Limitation Of The Study}

This study has been evaluated within a short period of time. The researcher has taken a limited sample size of 30 only. The findings of the study shall not be highly precise, if generalized for the Women entrepreneurs.

\section{9.. Analysis}

The data gathered with the help of questionnaire was subjected to a critical explanation and analysis in this paper. The explanation and analysis have been carried out by assessing the different types of women entrepreneurs.

\section{Table 1.1}

General Profile of Women Entrepreneurs

\begin{tabular}{|l|l|l|l|}
\hline General Factor & Classification & No of. Respondents & Percentage \\
\hline Age & $20-30$ Years & 4 & 13.33 \\
& $30-40$ Years & 11 & 36.66 \\
& $40-50$ Years & 8 & 26.66 \\
& Above 50 Years & 7 & 23.33 \\
\cline { 2 - 4 } & Total & 30 & 100 \\
\hline Education & Below SSLC & 5 & 16.66 \\
& SSLC & 8 & 26.66 \\
& Higher Secondary & 10 & 33.33 \\
& Degree & 7 & 23.33 \\
\cline { 2 - 4 } & Total & 30 & 100 \\
\hline Marital Status & Married & 21 & 70 \\
& Unmarried & 9 & 30 \\
\cline { 2 - 4 } & Total & 30 & 100 \\
\hline Types of Family & Joint family & 13 & 53.33 \\
& Nuclear family & 30 & 56.66 \\
\cline { 2 - 4 } & Total & & 100 \\
\hline
\end{tabular}




\begin{tabular}{|c|c|c|c|}
\hline \multirow[t]{5}{*}{ Size of the Family } & Up to 3 members & 4 & 13.33 \\
\hline & 4 members & 7 & 23.33 \\
\hline & 5 members & 10 & 33.33 \\
\hline & More than 5 member & 9 & 30 \\
\hline & Total & 30 & 100 \\
\hline \multirow[t]{4}{*}{ Nature of Business } & Manufacturing & 12 & 40 \\
\hline & Trading & 8 & 26.66 \\
\hline & Service & 10 & 33.33 \\
\hline & Total & 30 & 100 \\
\hline \multirow[t]{3}{*}{ Types of Ownership } & Sole proprietorship & 13 & 43.33 \\
\hline & Partnership & 17 & 56.66 \\
\hline & Total & 30 & 100 \\
\hline \multirow{5}{*}{$\begin{array}{l}\text { Initial Capital } \\
\text { Invested in the Business }\end{array}$} & Less than Rs.1,00,000 & 6 & 20 \\
\hline & Rs.1,00,000-Rs.3,00,000 & 11 & 36.66 \\
\hline & Rs.3,00,000-Rs.5,00,000 & 8 & 26.66 \\
\hline & Above Rs.5,00,000 & 5 & 16.66 \\
\hline & Total & 30 & 100 \\
\hline \multirow{4}{*}{$\begin{array}{ccc}\text { Sources } & \text { of } & \text { Initial } \\
\text { Capital } & & \end{array}$} & Own funds & 12 & 40 \\
\hline & Loan from banks & 8 & 26.66 \\
\hline & Loan from friends/relatives & 10 & 33.33 \\
\hline & Total & 30 & 100 \\
\hline \multirow[t]{5}{*}{ Monthly Income } & Less than Rs.10,000 & 9 & 30 \\
\hline & Rs.10,000-Rs.20,000 & 5 & 16.66 \\
\hline & Rs.20,000-Rs.30,000 & 12 & 40 \\
\hline & More than Rs.30,000 & 4 & 13.33 \\
\hline & Total & 30 & 100 \\
\hline \multirow{4}{*}{$\begin{array}{l}\text { Amount saved per } \\
\text { month }\end{array}$} & Less than Rs.1,000 & 7 & 23.33 \\
\hline & Rs.1,000-Rs.2,000 & 12 & 40 \\
\hline & More than Rs.2,000 & 11 & 36.66 \\
\hline & Total & 30 & 100 \\
\hline
\end{tabular}

\section{Inference:}

From the above Table 1.1 it isinferred that majority of the women entrepreneurs belong to the age group of 30 to 40 years $(36.66 \%)$ and $13.33 \%$ belong to the age group of 20 to 30 years. The survey reveals that highest portion of women entrepreneurs $(33.33 \%)$ have studied upto higher Secondary Education and those who have studied SSLC contribute the least percentage. Normally, married women have more task to execute and moral authorities to shoulder and hence mainly married women (70\%) living in a nuclear family are engaged in entrepreneurship. A greater part of women entrepreneurs (33.33\%) have a family which comprise of 5 members. Majority (40\%) of the women entrepreneurs carry on entrepreneurial activities in manufacturing industry. Only $33.33 \%$ are involved in service sector. The study found that $56.66 \%$ of women entrepreneurs are doing business in partnership firm and $43.33 \%$ of women entrepreneurs are sole proprietorship. $36.66 \%$ of the women entrepreneurs 
had invested an amount varying from Rs.1,00,000 to Rs.3,00,000 to start the enterprise. Majority (40\%) of the women entrepreneurs used their own funds to start the business without depending on banks, friends and relatives. The survey highlights the fact that a greater proportion of the women entrepreneurs (40\%) earn a net monthly income of up to Rs.20, 000 to Rs.30,000 followed by $30 \%$ of them earning a net monthly income less than Rs. 10,000 . A considerable proportion of women entrepreneurs (40\%) could save up to Rs.1,000 to 2,000. Only $23.33 \%$ of the women entrepreneurs save less than Rs.1,000 per month.

\section{Table 1.2}

Chi-Square Test

The relationship between the age of respondents and the overall problems faced by women entrepreneurs

\begin{tabular}{|c|c|c|c|c|}
\hline $\mathrm{O}$ & $\mathrm{E}$ & $(\mathrm{O}-\mathrm{E})$ & $(O-E)^{2}$ & $(O-E)^{2} / \mathrm{E}$ \\
\hline 1 & 1.8 & -0.8 & 0.64 & 0.355 \\
\hline 2 & 1.4 & 0.6 & 0.36 & 0.257 \\
\hline 1 & 1.6 & -0.6 & 0.36 & 0.225 \\
\hline 2 & 1.2 & 0.8 & 0.64 & 0.533 \\
\hline 1 & 2.7 & -1.7 & 2.89 & 1.070 \\
\hline 3 & 2.1 & 0.9 & 0.81 & 0.385 \\
\hline 3 & 2.4 & 0.6 & 0.36 & 0.15 \\
\hline 2 & 1.8 & 0.2 & 0.04 & 0.022 \\
\hline 5 & 2.4 & 2.6 & 6.76 & 2.816 \\
\hline 1 & 2 & -1 & 1 & 0.5 \\
\hline 1 & 2.1 & -1.1 & 1.21 & 0.576 \\
\hline 1 & 1.6 & -0.6 & 0.36 & 0.225 \\
\hline 2 & 2.1 & -0.1 & 0.01 & 0.004 \\
\hline 1 & 1.6 & -0.6 & 0.36 & 0.225 \\
\hline 3 & 2 & 1 & 1 & 0.5 \\
\hline 1 & 1.4 & -0.4 & 0.16 & 0.114 \\
\hline
\end{tabular}

Degrees of freedom $\quad=(\mathrm{r}-1)(\mathrm{c}-1)$

$=(4-1)(4-1)$

$=3 \times 3$

$=9$

It is ascertained from Table 1.2 the calculated value of $x^{2} 7.957$ is less than the table value of $x^{2}$ 16.92. Hence, the null hypothesis $\left(\mathrm{H}_{0}\right)$ is accepted and it is concluded that there is no significant relationship between age and their overall problems faced by women entrepreneurs.

\section{Findings}

$>40 \%$ of the women entrepreneurs carry on entrepreneurial activities in manufacturing sector.

The study found out that most of the women $(56.66 \%)$ entrepreneurs carry out entrepreneurial activity in partnership firm.

$36.66 \%$ of the women entrepreneurs have invested an amount ranging from Rs.1,00,000 to Rs. 3,00,000 to start the enterprise. 
Majority of the women entrepreneurs (40\%) started the businessusing their own funds without depending on banks, friends and relatives.

$>\quad$ The study reveals that majority of the women entrepreneurs (40\%) save Rs.1,000 to Rs.2,000 per month

When chi square test was applied, it was found that there is no significant relationship between age and the overall problems faced by women entrepreneurs.

\section{Suggestions}

Finance is the crucial problem faced by women entrepreneurs. Hence, the government and other financial institutions should giveinterest free loans to motivate women entrepreneurs.

Another vital problem faced by women entrepreneurs is marketing their goods. So marketing assistance must come up to help them in selling their goods effectively at reasonable prices.

\section{Conclusion}

It is evident from the study Women Entrepreneurs in Thoothukudi district face many problems. The research concludes that women entrepreneurs face constraints in the study area related to financial access, dispute betwixt work and family obligations, scarcity of raw materials and finding markets. If women entrepreneurs get support from family, society, Government and financial institutions, such constructive effort can open new direction for them and increase the marketability and profitability of business owned by them. Besides if the problems of women entrepreneurs are addressed correctly, they can come out successful entrepreneurs far better than men entrepreneurs.

\section{References}

\section{Books:}

Shanmukha Rao P. Women Entrepreneurial Development: Problems and Challenges, Discovery Publishing House, (2011).

2.SumanKalyanChaudhury Women Empowerment Through Entrepreneurs in India, SSDN Publishers (2012)[1]. Journals:

1. Kavita D. Chordiya Journal of Management and Research, ISSN: 2277-7830 Volume-2, Issue-1, March 2013

2. Manjula R. Iyer International Journal of Development Research, Volume 06, Issue 07, pp.8616-8620, July 2016.

Websites:

1. www.womenentrepreneursindia.com

2. www.entrepreneur.com 